\title{
A Review on Halal and Kosher Regulations, Certifications, and Industrial Practices
}

Amarul Arief Mohd Shuhaimi, Muhammad Shahrim Ab Karim, Siti Fatimah Mohamad, Ungku Fatimah Ungku Zainal Abidin, Mohd Mursyid Arshad

To Link this Article: http://dx.doi.org/10.6007/IJARBSS/v12-i2/12175 DOI:10.6007/IJARBSS/v12-i2/12175

Received: 18 December 2021, Revised: 22 January 2022, Accepted: 01 February 2022

Published Online: 23 February 2022

In-Text Citation: (Shuhaimi et al., 2022)

To Cite this Article: Shuhaimi, A. A. M., Karim, M. S. A., Mohamad, S. F., Abidin, U. F. U. Z., \& Arshad, M. M. (2022). A Review on Halal and Kosher Regulations, Certifications, and Industrial Practices. International Journal of Academic Research in Business and Social Sciences, 12(2), 182-192.

Copyright: (c) 2022 The Author(s)

Published by Human Resource Management Academic Research Society (www.hrmars.com)

This article is published under the Creative Commons Attribution (CC BY 4.0) license. Anyone may reproduce, distribute, translate and create derivative works of this article (for both commercial and non0-commercial purposes), subject to full attribution to the original publication and authors. The full terms of this license may be seen

at: http://creativecommons.org/licences/by/4.0/legalcode

Vol. 12, No. 2, 2022, Pg. $182-192$

Full Terms \& Conditions of access and use can be found at http://hrmars.com/index.php/pages/detail/publication-ethics 


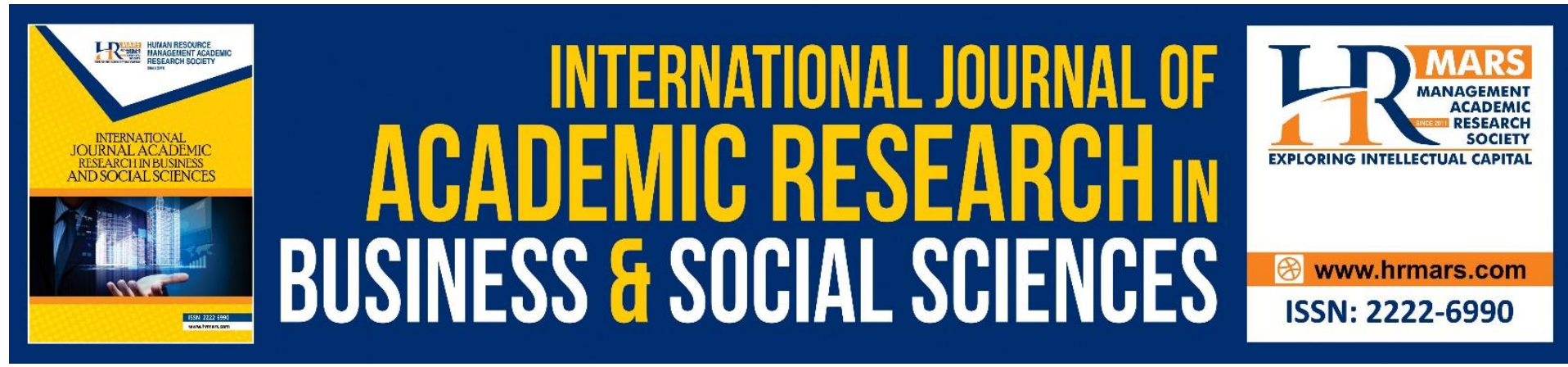

\title{
A Review on Halal and Kosher Regulations, Certifications, and Industrial Practices
}

\author{
Amarul Arief Mohd Shuhaimi, Muhammad Shahrim Ab Karim, \\ Siti Fatimah Mohamad, Ungku Fatimah Ungku Zainal Abidin, \\ Mohd Mursyid Arshad \\ University Putra Malaysia, Serdang, Selangor, Malaysia \\ Corresponding Author Email: shahrim@upm.edu.my
}

\begin{abstract}
Halal and Kosher generally may have shared certain attributes as both were originated within Abrahamic religions. The globalization and internalization of food industry has encouraged both dietary laws to pursue standards regulatory and procedures not only to preserve their laws and beliefs but also to provide better services to their respective markets around the globe. The purpose of this paper is to compare halal and kosher practices and in depth understanding of both laws and provide an overview of the industrial practices, regulations, and certifications of both laws in spearheading challenges in the current era. Reviews of past studies were made to get a grasp understanding in regard to these two dietary laws.
\end{abstract}

Keywords: Certifications, Halal, Industrial Practice, Kosher, Regulations.

\section{Introduction}

Religions have been part of human nature for centuries. To a certain extent, most religions provide lifestyle guidelines to their believers as part of devotion towards the faith that they believed in. These lifestyles are not only limited to performing prayers and how to communicate with one another, but also to the extent of food preparation and food consumptions amongst devotees which most of it is an obligation to be fulfilled and a topic of taboo to be argued (Abd Rahim et al., 2017). For instance, in Hinduism, they believe in the notion of ahimsa (non-injury to all living creatures); establishing the concept of vegetarianism amongst its believers (Fischer, 2016) that encourages the devotees to only consume vegetables and plant-based food in line with the notion. In the case of Islam and Judaism, these two Abrahamic faiths uphold certain dietary laws limiting their believers on what can be eaten (Motamedzadegan et al., 2018). In addition, not only both possess certain level of similarities between them in the aspect of concepts and origins, but also to the extent of practices and industrial exercises.

\section{Origin and Concepts of Kosher and Halal}

The term 'kosher' (literally means 'fit' or 'proper') represents the food consumption law of the Jewish (kashrut). It is Biblical in origin, mainly generated from the original five books of the Holy Scripture, the Torah that has been remained the same up to this date. During the 
acceptance of Ten Commandments on Mount Sinai by Moses, the tradition demonstrates that he also received verbal law which many years later narrated in the Talmud. As time goes by, the kosher laws have been construed and enacted by the rabbis to protect the believers from violating its fundamental essence and to restrain emerging issues and technologies that potentially affect the laws (Regenstein et al., 2003). Kosher dietary laws enhanced from four fundamental principles: prohibition of blood, permissible to consume animals' products, restriction of mixing dairy product with meats and forbidden animal parts for consumption such as sciatic nerve of mammals and fats reserved for fire-offering (Tieman \& Hassan, 2015). In fact, some of the scholars mentioned the prohibition to consume pork, shellfish, and rabbit. If one would consume mammal's animal, it must forgo a standard slaughtering process (referred as shechita) and has to be slaughtered by specially trained religious slaughter men called shochet, using a special knife named 'chalef': an extremely sharp with a very straight blade at least twice diameter of the neck of the animal (Abd Rahim et al., 2017). The blood of the slaughtered animal should be drained fully prior to consumption. Jews should only consume animals that are slaughtered according to this Jewish law.

Separation of dairy products and meat upon consuming is another fundamental element of this law. To ensure the meat and milk is separated completely, all equipment and ingredients must belong to a specific category. Upon consumption of meat, one must wait three to six hours before consuming dairy products (Abd Rahim et.al., 2017). Apart from these enlisted rules, some scholars also mentioned the prohibition to consume predatory and scavenger birds, rodents, reptiles, amphibians and milk, eggs, fat, organs of prohibited animals.

On the contrary, Halal (literally means permissible and permitted) is part of Syariah Law in Islamic teaching, derived from a verse in the holy book of Quran that emphasizes on the concept of Halalan Toyyiban. The word toyyiban is originated from the root word of toyyib portraying the meaning of wholesome, pure, clean, and nourishing while the word toyyiban conceptually uphold the concept of wholesomeness (Regenstein et al., 2003). As it is safe for devotees' health, akin to kosher, halal in Syariah law also induces on the prohibition of consuming certain types of food as they may harm the body of the consumers. The prohibition of consumption includes pig and other by products, blood, alcohol, carrion, meat that has not been slaughtered according to Islamic prescriptions (Regenstein et.al, 2003) that include (a) slaughtered with a sharp knife (b) slaughtered by a Muslim slaughterers and (c) the animals should be slaughtered in the name of Allah (Abd. Rahim et.al, 2017). Additionally, it also prohibits consuming animals whose blood is not fully drained, donkey and mule, dead animals, carnivorous animals, birds of prey, amphibians, all insects except for locust, animal reproductive organs, pancreas, and gall bladder.

Halal and kosher similarly instil precaution steps of process and procedures in consuming animals (slaughtering process) as both laws are highly concerned about animal welfare. In Islam, animal welfare is a huge part of the shariah (which narrated underneath the concept of figh muamalah or al-adah) describing the rulings of governing the relationship between man and other creation of Allah including animals and plants (Tieman \& Hassan, 2015). While in Judaism, kindness to animals is part of a strong foundation in the Torah; devotees should treat animal with kind and compassion even upon preparation for consumption. Therefore, both laws create such rules for slaughtering as this (especially the use of sharp knives to slaughter) is proven to minimalised the pain and stress of the animals compared to those commercial or other types of knives. 
The concept of doubt in halal food consumption is quite straightforward; the devotees are encouraged to avoid if any doubt is raised. All food (which include ingredients, processes, and preparations) should be segregated between halal and non-halal, depending on the product characteristics and market requirements mostly practiced in Muslim-majority countries such as Saudi Arabia, Malaysia, and Indonesia. In contrary, Judaism believers are encouraged to consult the rabbis upon encountering doubtful situation of food consumption. Segregation of food in kosher is also applicable where meat products, dairy products, and neutral products (widely known as pareve in kashrut) should be set apart to avoid confusions (Al-Teinaz et al., 2020).

Most religions obliging certain type of fasting on their believers as proves of devotions that unequivocally include Islam and Judaism. In Islam, fasting is compulsory during the month of Ramadhan from dawn to dusk and some other optional fasting days/period. However, exceptions may be applied upon certain unavoidable scenarios such as heavily pregnant women, manual labours or heavy workers, long-distance travellers or any other scenarios that may jeopardise health. Dissimilarly, fasting plays a major role in Jewish tradition whereby it is voluntary for bride and groom to fast during their solemnization day or in any other major or minor occasions (Teiman et. al., 2015). Despite of having medically proven impact of fasting on health, these two Biblical religions instilling different sorts of fasting to their believers.

\section{Overview of Halal and Kosher Market}

Islam is the fastest growing religion in the world; with approximately 1.8 billion followers (Kagan et al., 2020), halal market is seen to be growing rapidly fulfilling the needs of the international market. Distribution of Muslim population across the globe is scattered in many countries with $60 \%$ of the population is in Asia, $20 \%$ in North Africa and Middle East, and another $20 \%$ is in various other places. Majority Muslims can be seen in India, Indonesia, Malaysia, Pakistan, Turkey, Nigeria and Saudi Arabia. As the second largest religion in the world, halal industry is emerging on the global scale as it is not only vastly demanded in Muslim-majority countries, but the non-Muslim majority countries has also begun to see the bright prospect of this market. They began to initiate and develop home-grown halal industry, taking opportunity of this increasing population of the religion. Vanany (2021) discussed briefly about the halal food industry in China, where the local government began to extensively develop halal food industry not only to cater local demands, but also to focus on export-oriented sector. Edbiz Consulting (2013) as cited in Hong et al (2020) also explained about the expeditious development of the market, in which it is approximately worth US\$2.1bn with a total grown of 10 per cent of annual rate due to its large Muslim population and visitors. Another good example to this scenario is the white elephant country, Thailand; a majority-Buddhist nation has been listed in the top five amongst halal food producers amongst southeast-Asian countries. Not to mention South Korea and Japan that has its own halal food industry to cater to the demands of Muslim tourists at their respective countries. Halal industry around the globe not only has emerged within food industry market, but it has also gradually debouching into other sectors. Suhartanto (2020) in their paper on customer loyalty towards halal cosmetics has explicitly discussed on the emerging Halal cosmetics worldwide. Although the study indicated that customers loyalty is mainly driven by emotional attachment and product quality rather than religiosity aspect of it, yet the industry alone projected up to $\$ 39 \mathrm{~b}$ in 2018 globally and for a mediocre sector, the number proofs otherwise. The term Halal nowadays can also be observed in other economic activities such as hoteliers and tourisms. Although the term 'Halal tourism' is interchangeable with 'Islamic 
tourism' and a debatable matter (El-Gohary, 2016), the remarkable growth of the industry is not only in one segmentation (food). Khan and Haleem (2016) also mentioned on the 'Halal Pharmaceuticals' that guarantees pharmaceutical products do not contain pork or any ingredients derived from pork or other ingredients that is non-permissible in Islamic dietary laws. Norazmi (2015) acquainted briefly on the opportunity of this Halal segmentation industry as the Muslim population vastly grown every year making such industry relevant to be fixated upon. Although the economic contribution of the industry is not readily available, this is another evidence that Halal market is widely spread not only in daily consumable industry, but also escalated to various industry of economy.

Meanwhile, the growth of Jewish population remarks a different pattern especially in the post-World War II and the Shoah (also known as Holocaust). The world's Jewish community size represents a convergence of two very distinct migration patterns in Israel and the Diaspora. Israel's Jewish population grew linearly from an initial one-half million in 1945 to 630,000 in 1948 to more than 6.6 million in 2019. From an initial 10.5 million in 1945, the Jewish population of the Diaspora remained very stable until the beginning of the 1970s, when it began to decrease, reaching less than 8.1 million in 2019. The estimated population of the planet rose more than triple from 2,315 billion in 1945 to 7,621 billion by mid-2018. As a result, the proportional ratio of Jews in the world's overall population gradually declined from 4.75 per 1,000 in 1945 to 1.93 per 1,000 today - or one in 518 people in the world (DellaPergola, 2019, as cited in Dashefsky \& Sheskin, 2020).

Israel, as the largest kosher market in the globe, imports most of their kosher meat supply from South America: Argentina, Uruguay, and Paraguay. Kosher meat supply in the United States on the other hand mostly serves the domestic market. Argentinian beefs were once (from 2001 until 2019) banned from entering the United States market due to foot and mouth disease. In 2020, the States market has begun to admit the accessibility of Argentinian beef somehow affected the quality and availability of kosher beef supply in the United States (Kagan et al., 2020). The United States' kosher market generates more than 12 billion dollars annually in retail sales (Lytton, 2013) and only 8 percent of the kosher consumers are Jewish religion, while other consumers mainly come from health-conscious consumers, vegetarians, lactose intolerance consumers or those who satisfy the needs of non-Jewish religious requirement such as Halal.

As the ideology of Halal has permeated into the non-food industries such as hotel, tourism and cosmetic, the growth of Kosher industry is also seen to no longer stationary. Kosher market not only focusses on the supply chain of the meat, but supply meat on shelves in convenient stores. Studies on the emergence of Kosher into other types of economic industries are starting to loom. For instance, Moira (2017) who discussed on Kosher Tourism in Greece, proposed to enhance rational adaptation of tourism enterprise in the aim of increasing Jewish tourism flow of the respective countries. Although the emerging of Kosher ideology in other aspect of industries is limited as compared to the Halal industry, Kosher has begun to slowly permeate into other industries to fulfil the needs of the Jewish consumers worldwide.

\section{Regulations, Certifications, and Industrial Practices}

Rapid growth and demands on both dietary laws inflicted the enhancement of services in providing better and vast products and services. Hence, both dietary laws generated and employed various systems not only to help in providing better services to the market, but also to assist in preserving and conserving the ecosystem, that is erratically exposed to deficient 
and fraudulent. Al-Mazeedi (2013) explicitly discussed on undeclared ingredients in some of Halal and Kosher food productions. He adduced on the use of animal gelatines in food processing and preparations; while it may be permissible in certain dietary system but some violations in Halal and Kosher dietary laws is noticeable to certain extend especially the ones that made up from non-permissible ingredients such as lards and carnivores. Fuseini (2017) also mentioned on the existence of fraudulent in Halal meat industry that include and not limited to intentionally mislabelling non-Halal meat as Halal and contamination of Halal meat with non-Halal ingredients such as pork. An instance of Kosher Food Fraud case has also been reported where local butcher in Frankfurt sold faux kosher meats to Jewish-owned facilities such as nursing homes, private residences and Jewish schools (Sokol, 2015). These are just another proof that regulations and certifications of Halal and Kosher should be betided thoughtfully. Not to mention the reliability of Kosher certifications were once almost eradicated due to fraud and corruptions cases in the United States between mid-1800s and mid-1900s. It was estimated that up to 40 percent of Kosher meat productions during that period were not actually Kosher (Lytton, 2013). These acts of misconduct and violations against religious-based dietary laws compelled local authorities to enforce extensive regulations and certifications in products validation of Halal and Koshers food to scrutinize the quality and uphold the sanctity of the laws for the believers.

Despite the fact that Halal and Kosher are spreading around the globe, unlike monetary laws and regulations; both dietary laws do not have an international centralizedauthority body to monitor and enforce regulatory systems pertaining to their belief as it could be contributed from different cultural beliefs and different schools of thought within the respective religions. In Kosher, for instance, as reported by KosherFest, approximately over 900 kosher symbols are in-force for certification purposes throughout the globe (while in Kashrus Magazine list the numbers are almost 1400). A hechsher is known as the certification mark of the kosher certification. Some of the notable accreditation bodies within the UK include the London Beth Din, the London Board for Shechita, Sephardi Beth Din, the Joint Kashrus Committee of England, the Federation of Synagogues Kashrus, and the Manchester Beth Din. Some of the companies in the Europe opted to the US accreditation bodies, such as the New York based Orthodox Union, the largest kosher accreditation agency worldwide. London Beth Din on the other hand is the largest accreditation body in the UK and one of the largest kosher accreditation bodies in Europe and Asia (Kagan et al., 2020).

Regulation and certification of Kosher food has flourished extensively and quite complex, even to the extent of food preparation equipment prior to cooking, called Equipment Kosherisation. In the process of equipment Kosherisation, most local rabbis have formulated certain techniques and procedures in preparing kosher food equipment. If the process involves cooking, the equipment shall undergo the Kosherisation process especially if the equipment is interchangeable between pareve to diary, which in certain cases, need to be executed only in the presence of a rabbi (Featherstone, 2015). During the application of Kosher certifications, the applicants will be visited by qualified and trained Rabbinical Kahsrus Supervisors of the respective Kosher's certification agencies to validate and assess the readiness of the applicants in receiving the certifications. (Lytton, 2013). The adherence to the requirements and regulations of the Kosher certification agencies will only then be awarded with the certification. Some certifications shall be renewed in two years' time depending on the regulatory system of the agencies Some agencies even provide a regular basis-visit services to their certificate owners to audit the whole production processes. 
Generally, equipment and tools utilised in Halal food/products industries should not be contaminated with non-Halal ingredients to preserve its purification. Similar to Kosher food industry, the concept of purification can also be observed in Halal food production whereby contaminated equipment with non-Halal complying ingredients must undergo a cleansing and purification process. This cleansing and purification process is called Shariah Halal Ritual Cleansing and also known as Sertu. Ahmad \& Shariff (2015) explicitly discussed on the basic elements in cleansing contaminant equipment that include water, soil or agent of cleansing and procedure of cleansing. Malaysia Standard MS2400:2010 listed 5 fundamental measures in performing Sertu in industrial levels: (1) water, (2) product of cleansing such as soil or any other agent of cleansing, (3) procedure of cleansing (4) personnel who execute and verify the process and (5) documentation.

In term of regulatory and certifications system of Halal food industry, it is quite akin to Kosher regulatory system in which it is local-based system to monitor the productions of Halal food and merchandises in the respective countries. As for Malaysia, it is said to be one of the pioneer countries to establish their own Halal certification system in 1980's (Khan and Haleem, 2016) governed and funded by the local government. The govern inaugurated institution dedicated itself to manage and monitor any Halal-related producing, merchandising and supplying activities - Department of Islamic Development (also known as JAKIM, abbreviated from the official name in Malay language) to ensure the products comply to the Islamic dietary laws. The formation of Halal Certification Bodies (HCB) aims to independently verify halal status \& facilitate the trade in halal products (Al-Teinaz et al., 2020). Although there are large in numbers of Halal Certification Bodies around the globe, not many are recognisable and approved by local government in certain countries. For instance, in Indonesia, the Indonesia Council of Ulama (also known as Majelis Ulama Indonesia; MUI) only recognised 45 foreign Halal Certified Bodies while JAKIM of Malaysia recognised 84 Halal Certified Bodies around the globe. These recognitions are grounded on the capability of the foreign halal certification bodies in complying to local governments' procedures \& guidelines in producing raw material and products.

Apart from that, some countries regulated additional guideline to ensure the productivity of Halal products are from reliable sources. In Thailand, all Halal products suppliers are required to appoint Halal team which consists of personnel who have the authority and able to control and monitor production processes of Halal products (Central Islamic Council of Thailand, 2009). While in Malaysia, every Halal industry players is compelled to create a Halal Internal Committee (HIC) that consists of a minimum of 4 members in which two of them must be Muslim at the management level, one person is responsible on purchasing/procurement and another person will be responsible in managing Halal matters for the company as the coordinator of IHC. This coordinator, mainly known as Halal Executive/Supervisor must be knowledgeable and well-trained in Halal standard and certification requirements (Department of Islamic Development Malaysia Halal Hub Division. 2014). Despite of the placement of Halal representatives within the industry itself, there are still some cases of breaching Halal regulations and producing or importing questionable source of ingredients/raw meats were reported as happened in Malaysia (South China Morning Post, 2020). This could be happening due to the limitation of decision-making ability/lacking sense of authority bestowed upon them (Ahmad et al., 2018) and bribery amongst local government officers (Basyir, 2020) in performing tasks with integrity and honesty. 


\section{Future of Kosher and Halal}

Both dietary laws have a promising future in the global scale. Global demand will continue to expand, hence this expansion should also be parallel to the economic sector. As Halal has emerged to other sectors, Kosher should also emerge to other parts of economic activities rather than focussing on food and tourism industries. It has the potential of expansion to different types of markets that uphold the fundamental rules of the dietary law such as cosmetics and pharmaceutical industries. Studies on the relevance of emergence should be done to observe the readiness of the expansion in different economic sectors.

Apart from that, although Halal and Kosher practices came from different schools of thought within the respective religions that are localised and implemented according to the beliefs, the centralisation and internalisation of $\mathrm{Halal}$ and Kosher regulations and certifications should be conceptualised and developed as it will not only facilitate mutual benefits of corporations and industry players globally, but it will also help to stimulate a better regulatory system to the dietary laws. Additionally, this would also promotes better guidance to public consumers without confusions and hesitance. White and Samuel (2016) also explained on the absence of a global agreed standard for Halal may instil confusion among producers in adopting certification that would best achieve maximum recognition and growth. Not to mention confusion faced by consumers as abandons of logos and certifications are available in the market, yet some are recognisable in certain countries, others are not. Future studies should be able to uncover the challenges in developing such vision and how to overcome those challenges to ensure this centralisation and internationalization becomes a reality for both dietary laws.

On the other hand, the regulation to create a representative or supervising positions of Halal productions within the industry level is an applaudable notion. However, the inability or limitation in making substantial decisions of these representatives should be overcome immediately as these industries are producing goods to the mass market. The inability of these representatives in making substantial decisions will jeopardise the quality or the level of Halalan Toyiiban of the goods that are consumed. Rather than focusing solely on supervising productions and reporting, a higher and a more critical Halal positions should be established; corresponding to how critical this matter is to the dietary law and consumer perspectives. In-depth studies on these positions should be done to analyse their current conditions within the industry and what precautions and progressive steps should be done in overcoming such issues.

Halal and Kosher will continue to expand as their believers are growing gradually. Nevertheless, this expansion should not only be limited to the number of populations. Both have the potential to develop in many economic sectors, and due to these potentials, the quality of regulation and certification system should also be in line as it will help the industry to be more progressive in producing a better products and services to consumers. This would be a challenge to all religious scholars, legislation experts, researchers, and industry players yet it is a challenge worth the risk for a better future for both dietary laws.

This review leads to the conclusion that Halal and Kosher market is expandable even further globally and with that expectation, it has contributed to broaden knowledge in other aspects such as Human Resource Management pertaining to Halal and Kosher food industry as well as food integrity and food safety management of both dietary laws. In addition, the regulation and certification of both dietary laws are exposed to further development especially in terms of its centralization which would optimize the production and service efficiency of both markets worldwide. 


\section{References}

Abd Rahim, F. H., Muhammad, N. A. B., \& Hassan, F. H. (2017). Halal And Kosher Marketing Strategie. Journal Of Islamic Management Studies, 1(1), 104-116. Retrieved from http://publications.waim.my/index.php/jims/article/view/12

Adawi, M., Damiani, G., Bragazzi, N. L., Bridgewood, C., Pacifico, A., Conic, R. R., ... \& Watad, A. (2019). The impact of intermittent fasting (Ramadan fasting) on psoriatic arthritis disease activity, enthesitis, and dactylitis: A multicentre study. Nutrients, 11(3), 601.

Ahmad, N., \& Shariff, S. M. (2016). Supply Chain Management: Sertu Cleansing for Halal Logistics Integrity. Procedia Economics and Finance, 37, 418-425.

Ahmad, A. N., Abidin, U. F. U. Z., Othman, M., \& Rahman, R. A. (2018). Overview of Halal Food Control System in Malaysia. Food Control. doi: 10.1016/j.foodcont.2018.02.035

Al-Mazeedi, H. M., Regenstein, J. M., \& Riaz, M. N. (2013). The issue of undeclared ingredients in halal and kosher food production: A focus on processing aids. Comprehensive Reviews in Food Science and Food Safety, 12(2), 228-233.

Al-Teinaz, Y. R., Regenstein, J. M., Lever, J., Katme, A. M., \& Unsdorfer, S. (2020). The Halal and Kosher Food Experience in the UK. The Halal Food Handbook, 331-341.

Basyir, M. (2020). Meat cartel "bribing government officers." NST Online. https://www.nst.com.my/news/nation/2020/12/651038/meat-cartel-bribinggovernment-officers

Bozzo, G., Di Pinto, A., Bonerba, E., Ceci, E., Mottola, A., Roma, R., ... \& Celano, G. V. (2017). Kosher slaughter paradigms: Evaluation of slaughterhouse inspection procedures. Meat science, 128, 30-33.

Buckser, A. (1999). Keeping kosher: eating and social identity among the Jews of Denmark. Ethnology, 191-209.

Central of Islamic Council of Thailand. (2009). Regulation of the Central Islamic Council of Thailand on the Management of Halal Affairs B. E. 2558.

DellaPergola, S. (2019) Chapter 8: World Jewish Population 2019. In A. Dashefsky \& I. M. Sheskin (Eds). American Jewish Year Book 2019: The Annual Record of the North American Jewish Communities Since 1899 (Volume 119) (1st ed. 2020 ed.). Springer. https://doi.org/10.1007/978-3-030-40371-3

Della Corte, V., Del Gaudio, G., and Sepe, F. (2018), Ethical food and the kosher certification: a literature review. British Food Journal, Vol. 120 No. 10, pp. 2270-2288. https://doi.org/10.1108/BFJ-09-2017-0538

Department of Islamic Development Malaysia Halal Hub Division. (2014). Circular on Halal Certification Number 2, 2014. Implementation of Manual Procedure for Malaysia Halal Certification (third revision).

Edbiz Consulting. (2013). In Hong, M., Sun, S., Beg, A. R., \& Zhou, Z. (2018). Determinants of halal purchasing behaviour: evidences from China. Journal of Islamic Marketing.

Featherstone, S. (2015). Kosher and halal food regulations. A Complete Course in Canning and Related Processes, 63-68. doi:10.1016/B978-0-85709-677-7.00003-7

Fischer, J. (2016). Markets, religion, regulation: Kosher, halal and Hindu vegetarianism in global perspective. Geoforum, 69, 67-70.

Fischer, J. (2018). Kosher Biotech: Between Religion, Regulation, and Globalization. Religion and Society, 9(1), 52-67

Fuseini, A., Wotton, S. B., Knowles, T. G., \& Hadley, P. J. (2017). Halal meat fraud and safety issues in the UK: a review in the context of the European Union. Food Ethics, 1(2), $127-$ 142. 
Halal Malaysia. (n.d.). Halal Malaysia Official Portal. Retrieved March 16, 2021, from http://www.halal.gov.my/v4/index.php?data=bW9kdWxlcy9jZXJOaWZ5X2JvZHk7Ozs7 \&utama $=$ CB_LIST

Hamerman, E. J., Schneider, A. B., \& Rozensher, S. G. (2019). Disgust sensitivity and kosher food preferences among the non-Jewish population in the US. Appetite, 143, 104413

Imlan, J. C., Kaka, U., Goh, Y. M., Idrus, Z., Awad, E. A., Abubakar, A. A., ... \& Sazili, A. Q. (2020). Effects of Slaughter Knife Sharpness on Blood Biochemical and Electroencephalogram Changes in Cattle. Animals, 10(4), 579.

Jeong, E., \& Jang, S. (2020). Kosher labelling in restaurants: Examining the healthy halo effect. Journal of Foodservice Business Research, 23(1), 46-56.

Kamins, M. A., \& Marks, L. J. (1991). The perception of kosher as a third-party certification claim in advertising for familiar and unfamiliar brands. Journal of the Academy of Marketing Science, 19(3), 177-185.

Kagan, A., Draeger, K., \& Olive, R. (2020). Halal and Kosher Minnesota Meat Market Assessment: Analysis, Implications and Recommendations. UMN Extension Regional Sustainable Development Partnerships. Retrieved from the University of Minnesota Digital Conservancy, https://hdl.handle.net/11299/210220.

Karim, R. A., Mahmud, N., Marmaya, N. H., \& Hasan, H. F. A. (2020). The Use of Total Quality Management Practices for Halalan Toyyiban of Halal Food Products: Exploratory Factor Analysis the Use of Total Quality Management Practices for Halalan Toyyiban Of Halal Food Products: Exploratory Factor Analysis. Asia-Pacific Management Accounting Journal, 15(1), 1-20.

Khan, M. I., \& Haleem, A. (2016). Understanding halal and halal certification \& accreditation system: a brief review. Saudi Journal of Business and Management Studies, 1(1), 32-42.

Latif, I. A., Mohamed, Z., Sharifuddin, J., Abdullah, A. M., \& Ismail, M. M. (2014). A comparative analysis of global halal certification requirements. Journal of Food Products Marketing, 20(sup1), 85-101.

Lever, J. (2019). Halal Meat and Religious Slaughter: From Spatial Concealment to Social Controversy-Breaching the Boundaries of The Permissible? Environment and Planning C: Politics and Space, 37(5), 889-907.

Lytton, T. D. (2013). Kosher: Private Regulation in the Age of Industrial Food (Illustrated ed.). Harvard University Press. https://www.hup.harvard.edu/catalog.php?isbn=9780674072930

Majelis Ulama Indonesia. (2020). List of Approved Foreign Halal Certification Bodies Majelis Ulama Malaysia. https://www.halalmui.org/mui14/main/page/list-of-halalcertification-bodies

Mohezar, S., Zailani, S., \& Zainuddin, Z. (2016). Halal Cosmetics Adoption Among Young Muslim Consumers in Malaysia: Religiosity Concern. Global Journal Al-Thaqafah, 6(1), 47-59.

Moira, P., Mylonopoulos, D., \& Vasilopoulou, P. (2017). 13 Kosher Tourism: A Case Study. Conflicts. Religion and Culture in Tourism, 144. Cab International.

Motamedzadegan, A., Ebdali, S., \& Regenstein, J. M. (2018). Halal and Kosher Regulations for Processing and Marketing of Vegetables. Handbook of Vegetables and Vegetable Processing, 989-1002.

MS1500:2009 Halal Food - Production, Preparing, Handling and Storage - General Requirements. Second Revision. Department of Standards Malaysia (2009). 
MS2400:2010 Halalan-Toyyiban Assurance Pipeline: (Department of Standards Malaysia (2010): Part 1: Management System Requirements. for Transportation of Goods and/or Cargo Chain Service Part 2: Management System Requirements for Warehousing and Related Activities.

Norazmi, M. N., \& Lim, L. S. (2015). Halal pharmaceutical industry: opportunities and challenges. Trends in pharmacological sciences, 36(8), 496-497.

Regenstein, J. M., Chaudry, M. M., \& Regenstein, C. E. (2003). The kosher and halal food laws. Comprehensive reviews in food science and food safety, 2(3), 111-127.

Riaz, M. N., \& Chaudry, M. M. (2003). Halal food production. CRC press.

Riaz, M. N., \& Chaudry, M. M. (Eds.). (2018). Handbook of halal food production. CRC Press.

Silver, J. (2011). Understanding freedom of religion in a religious industry: Kosher slaughter (shechita) and animal welfare. Victoria U. Wellington L. Review, 42, 671.

Smith, J. (2019). John Lever and Johan Fischer: Religion, regulation, consumption: globalising kosher and halal markets. Agriculture and Human Values, 36(2), 365-366.

Sokol, S. (2015). Frankfurt butchers convicted in kosher meat fraud. The Jerusalem Post, available at: https://www.jpost.com/diaspora/frankfurt-butchers-convicted-in-koshermeat-fraud-399239.

South China Morning Post. (2020). Fake halal meat: Malaysia vows crackdown as scandal sparks outrage. South China Morning Post. https://www.scmp.com/news/asia/southeast-asia/article/3115837/malaysian-cartelallegedly-sold-fake-halal-meat-muslims-40

Suhartanto, D., Dean, D., Sarah, I. S., Hapsari, R., Amalia, F. A., \& Suhaeni, T. (2020). Does religiosity matter for customer loyalty? Evidence from halal cosmetics. Journal of Islamic Marketing.

Suryawan, A. S. (2019). John Lever, Johan Fischer, 2018: Religion, regulation, consumption: globalising kosher and halal markets.

Tieman, M., \& Hassan, F. H. (2015). Convergence of food systems: Kosher, Christian and Halal. British Food Journal.

Vanany, I., Hua Tan, K., Siswanto, N., Arvitrida, N.I. \& Pahlawan, F.M. (2021). Halal six sigma framework for defects reduction. Journal of Islamic Marketing, Vol. 12 No. 4, pp. 776793. https://doi.org/10.1108/JIMA-11-2019-0232

White, G. R., \& Samuel, A. (2016). Fairtrade and Halal food certification and labelling: Commercial lessons and religious rimitations. Journal of Micromarketing, 36(4), 388399. 